\title{
Study of Methylene Blue Degradation Using Mediated Electrochemical Oxidation With Ce (IV) Ions: Effect of Supporting Electrolyte, Ce (III) Concentration, and Oxidation Potential
}

\author{
Ummu Rokhima $^{1}$, Henry Setiyanto ${ }^{1 *}$, Muhammad Ali Zulfikar ${ }^{1}$, \\ Vienna Saraswaty ${ }^{2}$, Nandang Mufti ${ }^{3}$ \\ \{Corresponding author's email: henry@chem.itb.ac.id\}
}

\begin{abstract}
${ }^{1}$ Analytical Chemistry Research Group, Institut Teknologi Bandung, Bandung, Indonesia ${ }^{2}$ Research Unit for Clean Technology, Indonesian Institute of Sciences, Bandung, Indonesia

${ }^{3}$ Department of Physics, Universitas Negeri Malang, Malang, Indonesia
\end{abstract}

\begin{abstract}
Methylene Blue (MB) is a dye commonly used in the textile industry. Dyes waste from the textile industry harms the ecosystem of the environment. One method of textile dye waste degradation is mediated electrochemical oxidation. This method uses an oxidation-reduction process using metal ion as a mediator. The mediator metal ions act as an oxidizer which oxidizes textile dyes waste into simpler compounds. The mediator ion used in this study was Ce (IV) in acidic. The results of degradation were analyzed using voltammetry method. This study used carbon paste electrode as working electrode, platinum wire as auxiliary electrode, and $\mathrm{Ag} / \mathrm{AgCl}$ as reference electrode. The results of the cyclic voltammogram showed that the oxidation potential of $\mathrm{MB}$ is $0.2880 \mathrm{~V}$ while $\mathrm{Ce}(\mathrm{III}) / \mathrm{Ce}(\mathrm{IV})$ in $\mathrm{H}_{2} \mathrm{SO}_{4}$ has oxidation and reduction potentials $1.2400 \mathrm{~V}$ and $0.4520 \mathrm{~V}$. This potential indicates that MB oxidation potential was not disturbed by mediator ion potential. The optimum condition of degradation was obtained at $250 \mathrm{ppm}$ MB with 0.015 $\mathrm{M} \mathrm{Ce}(\mathrm{III})$ and $0.2 \mathrm{M} \mathrm{H}_{2} \mathrm{SO}_{4}$ for 30 minutes using the potential of $6 \mathrm{~V}$.
\end{abstract}

Keywords: Methylene Blue, MEO, Degradation, Cerium.

\section{Introduction}

The dye compounds are widely used in food, cosmetics, medicine, paper, and textile industries. The industry that uses the most dyes is textiles. Methylene Blue (MB) is a basic dye that is commonly used in the textile industry. The textile industry is currently developing rapidly in Indonesia. The dye waste used during the production process is discharged into the environment. The waste from the textile industry harms environmental ecosystems, especially aquatic ecosystems, such as increased water toxicity. Many synthetic dyes are toxic and carcinogenic [1].

The waste water from textile industry needs to be treated before being discharged into the environment. One method of textile dye waste degradation is electrochemical [2]. In addition electrochemical methods can be used as a low-cost analysis for both organic compounds and metal ions [3,4]. This method can also be used to determine the reactivity of various types of drugs [5-10]. 
Electrochemical has high efficiency and can be carried out at relatively low temperatures, such as room temperature. The resulting degradation products are not dangerous. The electrodegradation method that has been studied and developed quite well is mediated electrochemical oxidation (MEO) $[11,12]$. MEO is an oxidation-reduction process by using metal mediators ion. Mediation with metal ion aims to speed up the reaction and make the reaction occur in more comfortable place [13].

In the MEO, the mediator ion acts as an oxidizer which oxidizes textile dye waste to $\mathrm{CO}_{2}$ and $\mathrm{H}_{2} \mathrm{O}$. The mediator ion is used $\mathrm{Ce}$ (IV) in the acidic. The advantage of the MEO are the process are fast, efficient, does not generate new waste, and mediator ion can be repeated use of oxidizers during the degradation process. It was conducted at atmospheric pressure, room temperature, and acidic atmosphere [14]. In this paper, MEO of MB using platinum wire as anode and cathode at different operating conditions are studied and discussed.

\section{Experimental Section}

\subsection{Materials and Instrumentation}

The materials in this study were $\mathrm{MB}, \mathrm{Ce}_{2}\left(\mathrm{SO}_{4}\right)_{3} .8 \mathrm{H}_{2} \mathrm{O}, \mathrm{H}_{2} \mathrm{SO}_{4}, \mathrm{HNO}_{3}, \mathrm{HCl}, \mathrm{K} 3 \mathrm{Fe}(\mathrm{CN})_{6}$, $\mathrm{K}_{4} \mathrm{Fe}(\mathrm{CN})_{6}$, and $\mathrm{NaCl}$. All solution was prepared by dissolving in distilled water. Pt wire was used for anode and cathode electrodes for degradation. The electrochemical studies by cyclic voltammetry $(\mathrm{CV})$ and differential pulse voltammetry (DPV) using eDAQ potentiostat with three electrodes system. There are carbon paste electrode as the working electrode, $\mathrm{Ag} / \mathrm{AgCl}$ (saturated $\mathrm{NaCl}$ ) as reference electrode, and $\mathrm{Pt}$ wire as auxiliary electrode. All potentials are given concerning the $\mathrm{Ag} / \mathrm{AgCl}$ reference electrode.

\subsection{Methods}

Experiments were carried out in an electrochemical cell containing $10 \mathrm{ml}$ of dyes for each experiment and using Pt wire for anode and cathode. Dye solution of $250 \mathrm{ppm}$ was chosen as a working solution and a known amount of supporting electrolyte was added. The experiments were conducted under atmospheric pressure and at room temperature. Degradation was analyzed by calculating the percent of degradation (\% degradation) using the voltammetry method. Percent of degradation is calculated with the formula

$$
\% \text { degradation }=\frac{\mathrm{I}_{\text {initial }}-\mathrm{I}_{\text {final }}}{\mathrm{I}_{\text {initial }}} \times 100 \%
$$

when we obtained from the measurement using voltammetry. 


\section{Results and Discussion}

\subsection{Characterization of Ag/AgCl Reference Electrode}

$\mathrm{Ag} / \mathrm{AgCl}$ electrode was characterized using mixture of $0.01 \mathrm{M} \mathrm{K}_{3} \mathrm{Fe}(\mathrm{CN})_{6}, \mathrm{~K}_{4} \mathrm{Fe}(\mathrm{CN})_{6}$, and $0.1 \mathrm{M} \mathrm{NaCl}$ solution. Characterization is performed using $\mathrm{CV}$ with a range of potential given is $-400 \mathrm{mV}$ to $800 \mathrm{mV}$ with a scan rate of $100 \mathrm{mV} . \mathrm{s}^{-1} . \mathrm{Ag} / \mathrm{AgCl}$ voltammogram electrodes were compared with BAS. Voltammograms comparison of $\mathrm{BAS}$ and $\mathrm{Ag} / \mathrm{AgCl}$ can be seen in Figure 1.

The oxidation peak that appears on the voltammogram comes from the oxidation reaction of $\mathrm{K}_{4} \mathrm{Fe}(\mathrm{CN})_{6}$ to $\mathrm{K}_{3} \mathrm{Fe}(\mathrm{CN})_{6}$. Meanwhile, the reduction peak that appears on the voltammogram comes from the reduction reaction of $\mathrm{K}_{3} \mathrm{Fe}(\mathrm{CN})_{6}$ to $\mathrm{K}_{4} \mathrm{Fe}(\mathrm{CN})_{6}$. The results of data measurements of the current peak and potential contained in Table 1. Voltammogram BAS and $\mathrm{Ag} / \mathrm{AgCl}$ electrode appear to coincide. The formal potential of BAS and $\mathrm{Ag} / \mathrm{AgCl}$ electrodes were $0.1975 \mathrm{~V}$ and $0.1990 \mathrm{~V}$. Meanwhile, the ratio of anodic peak current to cathodic peak current $(\mathrm{Ipa} / \mathrm{Ipc})$ for BAS and $\mathrm{Ag} / \mathrm{AgCl}$ electrodes were 1.07 and 1.09. This showed that the reaction is reversible because the ratio of anodic peak current to the cathodic peak current (Ipa/Ipc) is close to one [15].

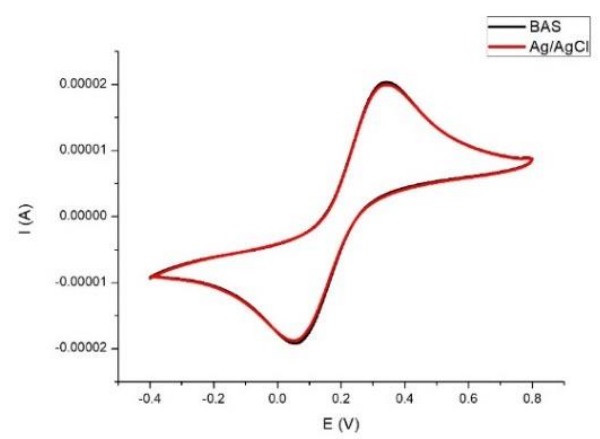

Fig. 1. Cyclic voltammogram of reference electrodes in $0.01 \mathrm{M} \mathrm{K} 3 \mathrm{Fe}(\mathrm{CN}) 6, \mathrm{~K} 4 \mathrm{Fe}(\mathrm{CN}) 6$ and $0.1 \mathrm{M}$ $\mathrm{NaCl}$ solution.

Table 1. Electrochemical data from cyclic voltammetry of comparative reference electrodes in $0.01 \mathrm{M} \mathrm{K} 3 \mathrm{Fe}(\mathrm{CN}) 6, \mathrm{~K} 4 \mathrm{Fe}(\mathrm{CN}) 6$ and $0.1 \mathrm{M} \mathrm{NaCl}$ solution.

\begin{tabular}{lllll}
\hline Reference Electrode & $\Delta \operatorname{Ipa}(\mathrm{mA})$ & $\mathrm{Epa}(\mathrm{V})$ & $\Delta \mathrm{Ipc}(\mathrm{mA})$ & Epc $(\mathrm{V})$ \\
\hline $\mathrm{BAS}$ & 0.0191 & 0.3310 & -0.0179 & 0.0640 \\
$\mathrm{Ag} / \mathrm{AgCl}$ & 0.0187 & 0.3310 & -0.0172 & 0.0670 \\
\hline
\end{tabular}

\subsection{Characterization of Carbon Paste Electrode}

Characterization carbon paste electrodes (CPE) were performed using $\mathrm{CV}$ with a range of potential given is $-400 \mathrm{mV}$ to $800 \mathrm{mV}$ with a scan rate of $100 \mathrm{mV} . \mathrm{s}^{-1}$. The sample solution was a mixture of $0.01 \mathrm{M} \mathrm{K}_{3} \mathrm{Fe}(\mathrm{CN})_{6}, \mathrm{~K}_{4} \mathrm{Fe}(\mathrm{CN})_{6}$ and $0.1 \mathrm{M} \mathrm{NaCl}$. Electrodes were obtained and 
compared with one another. A comparison of CPE voltammograms can be seen in Figure 2. The results of data measurement peak current and potential contained in Table 2. Carbon paste electrodes were selected that have the same peak current and oxidation potential.

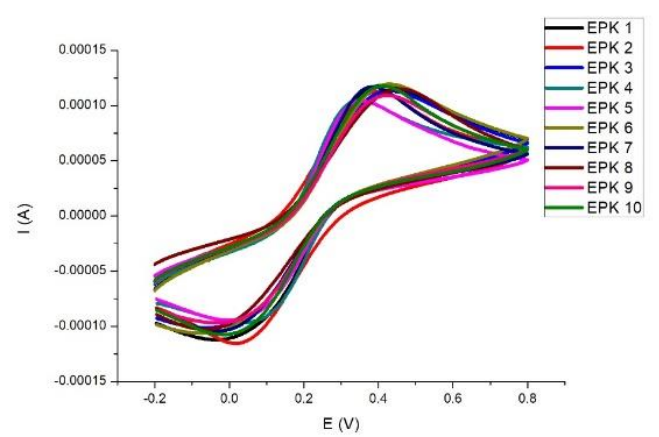

Fig. 2. Cyclic voltammogram of working electrodes comparative in $0.01 \mathrm{M} \mathrm{K} 3 \mathrm{Fe}(\mathrm{CN}) 6, \mathrm{~K} 4 \mathrm{Fe}(\mathrm{CN}) 6$, and $0.1 \mathrm{M} \mathrm{NaCl}$ solution.

Table 2. Electrochemical data from cyclic voltammetry of working electrodes comparative in $0.01 \mathrm{M} \mathrm{K} 3 \mathrm{Fe}(\mathrm{CN}) 6, \mathrm{~K} 4 \mathrm{Fe}(\mathrm{CN}) 6$ and $0.1 \mathrm{M} \mathrm{NaCl}$ solution.

\begin{tabular}{cll}
\hline Carbon Paste Electrode & Ipa $(\mu \mathrm{A})$ & Epa $(\mathrm{V})$ \\
\hline CPE 1 & 99.100 & 0.3800 \\
CPE 2 & 92.457 & 0.3860 \\
CPE 3 & 94.909 & 0.4050 \\
CPE 4 & 96.933 & 0.3360 \\
CPE 5 & 98.200 & 0.3450 \\
CPE 6 & 93.632 & 0.4050 \\
CPE 7 & 98.240 & 0.3700 \\
CPE 8 & 95.248 & 0.3710 \\
CPE 9 & 90.342 & 0.4000 \\
CPE 10 & 97.928 & 0.3960 \\
\hline
\end{tabular}

\subsection{Determination Potential of $\mathrm{MB}, \mathrm{Ce}(\mathrm{III}) / \mathrm{Ce}(\mathrm{IV})$ and $\mathrm{H}_{2} \mathrm{SO}_{4}$}

Determination potential of $\mathrm{MB}, \mathrm{Ce}(\mathrm{III}) / \mathrm{Ce}(\mathrm{IV})$ and $\mathrm{H}_{2} \mathrm{SO}_{4}$ redox reaction system using cyclic voltammetry. The reference electrode and working electrode used $\mathrm{Ag} / \mathrm{AgCl}$ and $\mathrm{CPE}$ that have been characterized. The voltammogram of these solutions can be found in Figures 3, 4, and 5. Each solution were scanning using CV with a potential range from $-200 \mathrm{mV}$ to 1800 $\mathrm{mV}$ and scan rate of $100 \mathrm{mV} . \mathrm{s}^{-1}$. In Figure 3, MB oxidation potential was obtained at $0.2880 \mathrm{~V}$ with anodic peak current is $1.50 \mu \mathrm{A}$.

Oxidation and reduction potential $\mathrm{Ce}(\mathrm{III}) / \mathrm{Ce}(\mathrm{IV})$ were $1.2520 \mathrm{~V}$ and $0.4520 \mathrm{~V}$. The oxidation potential generated was similar to the research conducted by Fang et.al [16]. The oxidation peak current was $40.659 \mu \mathrm{A}$ while the reduction peak current was $-28.541 \mu \mathrm{A}$. In Figure $5, \mathrm{H}_{2} \mathrm{SO}_{4}$ oxidation potential values are $0.5500 \mathrm{~V}$ and $1.3680 \mathrm{~V}$. While the reduction potential values are $0.2940 \mathrm{~V}$ and $1.0100 \mathrm{~V}$. 
The oxidation potential of MB is not disturbed by the potential of other solutions. MB oxidation peak will be used as a calculation of percent degradation by measuring the oxidation peak current before and after degradation.

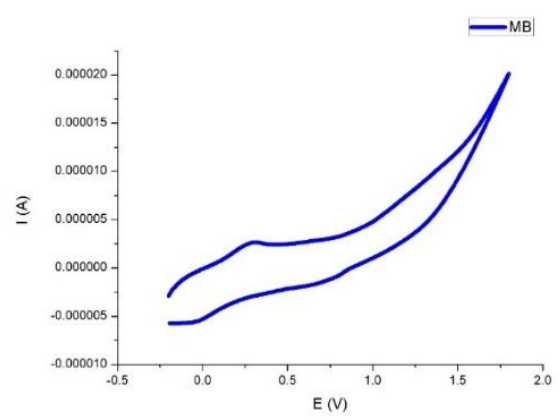

Fig. 3. Cyclic Voltammogram of 250 ppm MB.

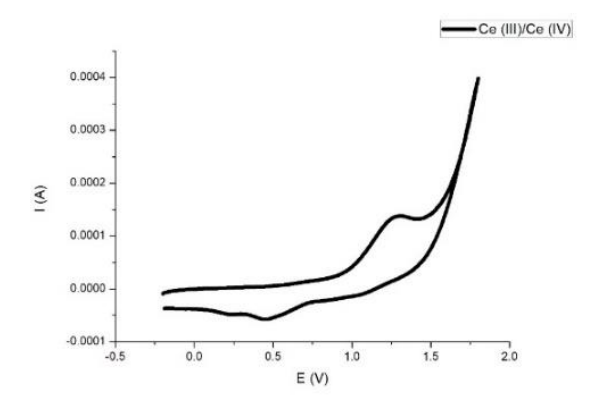

Fig. 4. Cyclic Voltammogram of $0.02 \mathrm{M} \mathrm{Ce(III)/Ce(IV)} \mathrm{system.}$

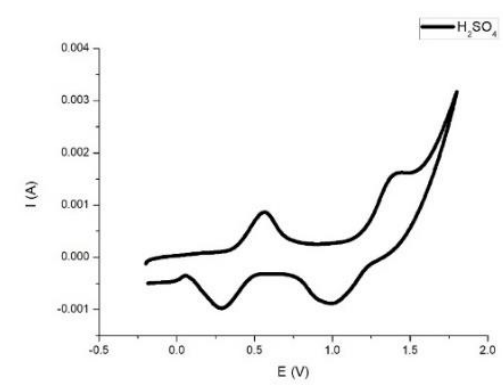

Fig. 5. Cyclic voltammogram of $0.3 \mathrm{M} \mathrm{H}_{2} \mathrm{SO}_{4}$.

\subsection{Determination of Supporting Electrolyte}

In the experiment, the effect of different supporting electrolyte for $\mathrm{Ce}(\mathrm{III}) / \mathrm{Ce}(\mathrm{IV})$ was studied using CV with scanning potentials ranging from $-200 \mathrm{mV}$ to $1800 \mathrm{mV}$ with scan rate $100 \mathrm{~m} . \mathrm{s}^{-1}$. The effect of supporting electrolytes are depicted in Figure 6. For oxidation Ce(III) 
maximum peak current was obtained at $\mathrm{H}_{2} \mathrm{SO}_{4}$ with $0.30 \mathrm{~mA}$, while using $\mathrm{HNO}_{3}$ is $0.06 \mathrm{~mA}$ and $\mathrm{HCl}$ doesn't produce peaks [17].

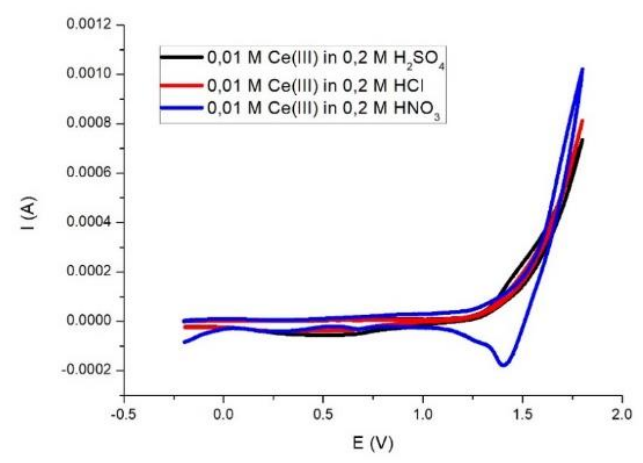

Fig. 6. Cyclic voltammogram of $\mathrm{Ce}(\mathrm{III})$ in various supporting electrolytes.

Based on the results of supporting electrolytes, it is known that $\mathrm{H}_{2} \mathrm{SO}_{4}$ is the supporting electrolyte which provides the best oxidation peak. Optimization of electrolyte concentrations $\mathrm{H}_{2} \mathrm{SO}_{4}$ for $\mathrm{Ce}$ (III) is carried out. The analytical method used CV with scanning potentials ranging from $-200 \mathrm{mV}$ to $1800 \mathrm{mV}$ with scan rate $100 \mathrm{~m} \cdot \mathrm{s}^{-1}$. Ce (III) oxidation peak current at various $\mathrm{H}_{2} \mathrm{SO}_{4}$ concentrations can be seen in Table 3 .

From the results, $0.2 \mathrm{M} \mathrm{H}_{2} \mathrm{SO}_{4}$ has an oxidation peak of $0.18 \mathrm{~mA}$. The difference in the peak oxidation current between a concentration of 0.20 and $0.30 \mathrm{M}$ is not too significant so that the $0.2 \mathrm{M} \mathrm{H}_{2} \mathrm{SO}_{4}$ concentration was chosen as the optimum supporting electrolyte condition. High concentrations of sulfuric acid produce large capacitive currents. Capacitive currents will disrupt the process of reading the peak current from the oxidation of Ce (III).

Table 3. Electrochemical data from cyclic voltammetry of various $\mathrm{H} 2 \mathrm{SO} 4$ concentration.

\begin{tabular}{ccc}
\hline$\left[\mathrm{H}_{2} \mathrm{SO}_{4}\right](\mathrm{M})$ & $\mathrm{Ipa}(\mathrm{mA})$ & $\mathrm{Epa}(\mathrm{V})$ \\
\hline 0.10 & 0.15 & 1.2480 \\
0.15 & 0.17 & 1.2400 \\
0.20 & 0.18 & 1.2400 \\
0.25 & 0.18 & 1.2440 \\
0.30 & 0.18 & 1.2500 \\
\hline
\end{tabular}

\subsection{Effect of Ce (III) Concentration}

The sample weas $250 \mathrm{ppm} \mathrm{MB}$ in $0.3 \mathrm{M} \mathrm{H}_{2} \mathrm{SO}_{4}$ solution with the addition of $\mathrm{Ce}(\mathrm{III})$ at various concentrations used starting from $0.01 \mathrm{M}-0.03 \mathrm{M}$ with an interval of $0.005 \mathrm{M}$. The degradation process was carried out within 10 minutes at a constant voltage of $6 \mathrm{~V}$. Samples were analyzed before and after degradation using CV. The effect of Ce (III) concentration is shown in Figure 7. In the range Ce (III) concentration increased the percentage of degradation. The increase in Ce (IV) production with an increase amount of MB degradation. It can be concluded that the concentration of Ce (III) is used a concentration of $0.015 \mathrm{M}$. The relatively small concentration of Ce (III) is used so as not to produce metal ion by-products with large concentrations. 


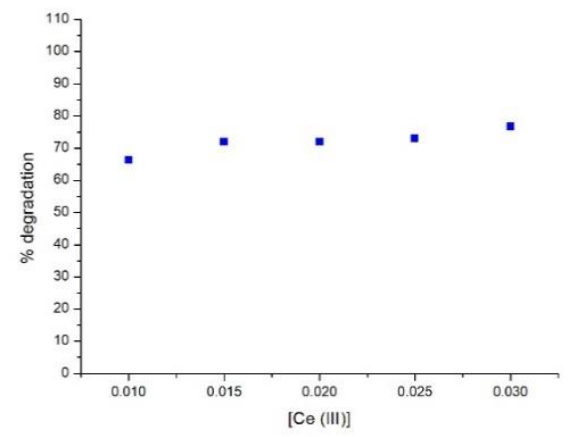

Fig. 7. Effect of Ce (III) concentration on the degradation of methylene blue.

\subsection{Effect of Oxidation Potential}

The potential is varied using a power supply between $1.5 \mathrm{~V}$ to $9 \mathrm{~V}$. Samples were used in two types, first a mixture of $250 \mathrm{ppm} \mathrm{MB}, 0.3 \mathrm{M} \mathrm{H}_{2} \mathrm{SO}_{4}$ and $0.02 \mathrm{M} \mathrm{Ce}$ (III) solution. Second a mixture of $250 \mathrm{ppm} \mathrm{MB}$ and $0.3 \mathrm{M} \mathrm{H}_{2} \mathrm{SO}_{4}$. The degradation process was carried out within 10 minutes. Samples were analyzed before and after degradation using CV. The result is shown in Figures 8. The percentage of degradation increases with increasing potential. The potential 9 $\mathrm{V}$ gives the highest percent degradation when compared to the others. Besides, the results of this optimization that degradation process using Ce (III) can be faster than without Ce (III). The percent of degradation of the first mixture is greater than the second without $\mathrm{Ce}(\mathrm{III})$ [14].

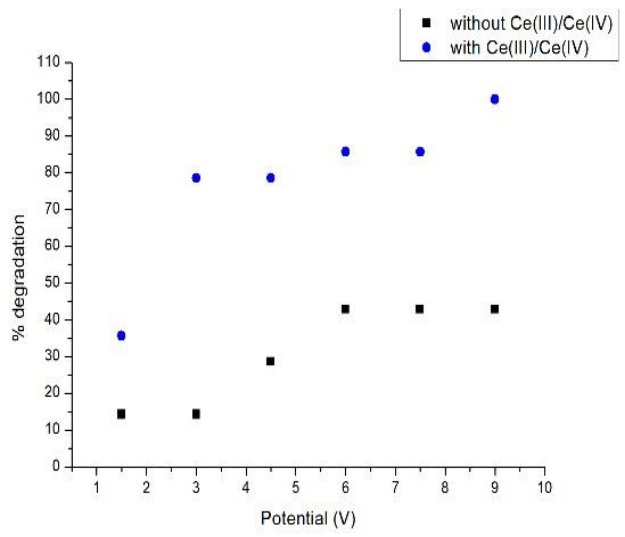

Fig. 8. Effect of potential use on the degradation of methylene blue.

\subsection{Effect of Time Degradation}

The degradation period used at these experiments was $10-60$ minutes. The samples were $250 \mathrm{ppm} \mathrm{MB}, 0.3 \mathrm{M} \mathrm{H}_{2} \mathrm{SO}_{4}$ and $0.02 \mathrm{M} \mathrm{Ce}$ (III). Meanwhile, the potential difference used was $6 \mathrm{~V}$. The result is shown in Figures 9. Percent degradation is directly proportional to the time. Maximum degradation in the range is obtained during degradation for $30-60$ minutes, 
increasing the value of percent degradation is almost constant. Therefore, the optimal time from MB degradation is 30 minutes with a percent of degradation value of $100 \%$.

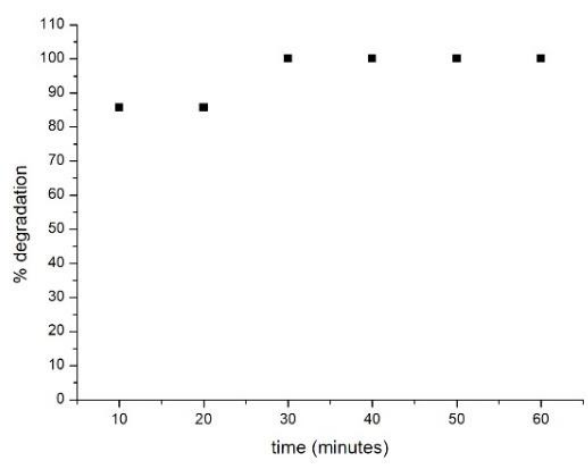

Fig. 9. Effect of time used on the degradation of methylene blue.

The optimum condition of electrodegradation was obtained at $250 \mathrm{ppm} \mathrm{MB}, 0.015 \mathrm{Ce}$ (III) and $0.2 \mathrm{M} \mathrm{H}_{2} \mathrm{SO}_{4}$ for 30 minutes using the potential of $6 \mathrm{~V}$. Samples were analyzed before and after degradation using DPV with scanning potentials ranging from $-200 \mathrm{mV}$ to $1600 \mathrm{mV}$ with scan rate $100 \mathrm{mV} . \mathrm{s}^{-1}$. From these results obtained that percent degradation MB was $75.44 \%$. The system of $\mathrm{Ce}(\mathrm{III}) / \mathrm{Ce}(\mathrm{IV})$ acts as mediator ion, first $\mathrm{Ce}(\mathrm{III})$ oxidation forms $\mathrm{Ce}(\mathrm{IV}) . \mathrm{Ce}(\mathrm{IV})$ oxidize $\mathrm{MB}$ to $\mathrm{CO}_{2}$ and $\mathrm{H}_{2} \mathrm{O}$. The reaction equation is as follows [18-20].

$$
\begin{aligned}
& \mathrm{Ce}^{3+}(\mathrm{aq}) \rightleftharpoons \mathrm{Ce}^{4+}(\mathrm{aq})+\mathrm{e}^{-} \\
& \mathrm{Ce}^{4+}(\mathrm{aq})+\mathrm{MB}(\mathrm{aq}) \rightarrow \mathrm{Ce}^{3+}(\mathrm{aq})+\mathrm{CO}_{2}+\mathrm{H}_{2} \mathrm{O}
\end{aligned}
$$

\section{Conclusions}

The mediated electrochemical oxidation process was successfully developed with Ce (IV) as the ion mediator and applied for the degradation of MB. The effects of various parameters such as supporting electrolytes, Ce (III) concentration, oxidation potential and time of degradation were studied. The optimum condition for maximum degradation of $250 \mathrm{ppm} \mathrm{MB}$ was observed to be the following : $0.015 \mathrm{M} \mathrm{Ce}$ (III) in $0.2 \mathrm{M} \mathrm{H}_{2} \mathrm{SO}_{4}$ for 30 minutes using the potential $6 \mathrm{~V}$ with percent degradation of $75.44 \%$.

Acknowlegment. The authors are very grateful to Hibah PDUPT 2019 Ristekdikti for their financial support for this research study. 


\section{References}

[1] Indu, M.S.: Electrochemical Oxidation Of Methylene Blue Using Lead Acid Battery Anode. 9, pp. 70-74. Procedia APCBEE, (2014)

[2] Setiyanto, H., Agustina, D., Zulfikar, M.A. and Saraswaty, V.: Study of the Fenton Reaction for Degradation of Remazol Red B in Textile Waste Industry. 11(2), pp. 168-179, Molekul, (2016)

[3] Rahmadhani, S., Setiyanto, H. and Zulfikar, M.A.: Fabrication of Carbon Paste Electrode Modified with Phenol Imprinted Polyaniline as a Sensor for Phenol Analysis by Potentiometry. 936, pp. 71-76, Materials Science Forum, (2018)

[4] Rahmadhani, S., Setiyanto, H. and Zulfikar, M.A.: Electropolymerized of Aniline as a New Molecularly Imprinted Polymer for Determination of Phenol: A Study for Phenol Sensor. pp. 124-128, International Seminar on Sensors, Insrumentation, Measurement and Metrology (ISSIMM), (2017)

[5] Bussy, U., Boisseaau, R., Thobie-Gautier, C. and Boujtita, M.: Electrochemistry-Mass Spectrometry to Study Reactive Drugs Metabolites and CYP450 Simulations. 70, pp. 67-73, Trends in Analytical Chemistry, (2015)

[6] Alvarez-Lueje, A., Perez, M. and Zapata, C.: Electrochemical Methods for the In Vitro Assessment of Drug Metabolism. Pp. 221-246, Topics on Drug Metabolism, (2012)

[7] Stalder, R. and Roth, G.P.: Preparative Microfluidic Electrosynthesis of Drug Metabolites. 4(11), pp. 1119-1123, Medical Chemistry Letters, (2013)

[8] Setiyanto, H., Saraswaty, V., Hertadi, R. and Buchari, B.: Determination of the Reactivity of the Anti-cancer Nitrogen Mustard-Mechlorethamine : A Cyclic Voltammetric Investigation. 7(6), pp. 657665, Analytical and Bioanalytical Electrochemistry, (2015)

[9] Setiyanto, H., Saraswaty, V., Hertadi, R., Noviandri, I. and Buchari, B.: Chemical Reactivity of Chlorambucil in Organic Solvents: Influence of 4-Chloro Butyronitrile Nucleophile to Voltammogram Profiles. 6, pp. 2090-2100, International Journal of Electrochemical Science, (2011)

[10] Setiyanto, H., Saraswaty, V., Hertadi, R., Noviandri, I. and Buchari, B.: Cyclic Voltammetric Study of Chlorambucil in The Presence of 4-Chloro Butyronitrile in Aqueous Solution. 3(4), pp. 19861992, International Journal of ChemTech Research, (2011)

[11] Panizza, M.: Electrochemical Degradation Of Methylene Blue. 54, pp. 382-386. Separation Purification Technology, (2006)

[12] Setiyanto, H., Adyatmika, I.M., Syafullah, M.M. and Zulfikar, M.M.: Mediated Electrochemical Oxidation (MEO) Process: A Study of Nonylphenol Ethoxylates (NPE) Oxidation in Batch Mode Using Cerium (IV) Oxidant. 1013(1), pp. 012201, Journal of Physics: Conference Series, (2018)

[13] Carlos, A.: Electrochemical Oxidation Of Organic Pollutants For The Wastewater Treatment: Direct and Indirect Processes. 35, pp. 1324-1340. Chemical Society Reviews, (2006)

[14] Balaji, S.: Cerium (IV)-Mediated Electrochemical Oxidation Process For Destruction of Organic Pollutants in A Batch and A Continuous Flow Reactor. 24, pp. 1009-1016. Korean Journal Chemistry, (2007)

[15] Wang, J.: Analytical Electrochemistry 2nd Ed, New York: John Wiley and Sons, (2002).

[16] Fang, B.: A Study of The Ce(III)/Ce(IV) Redox Couple For Redox Flow Battery Application. 47, pp. 3971-3976. Electrochim Acta, (2002)

[17] Paulenova, A.: Redox Potentials and Kinetics of The $\mathrm{Ce}^{3+} / \mathrm{Ce}^{4+}$ Redox Reaction and Solubility of Cerium Sulfates in Sulfuric Acid Solution. 109, pp. 431-438. Journal of Power Sources, (2002)

[18] Palinasami, N.: Cerium (IV)-mediated Electrochemical Oxidation Process for Removal of Polychlorinated dibenzo-p-dioxins and dibenzofurans. 2409, pp. 1-4. Journal of Industrial and Engineering Chemistry, (2015)

[19] Panizza, M.: Direct and Mediated Anodic Oxidation of Organic Pollutants. 109, pp. 6541-6569. Chemical Reviews, (2009)

[20] Raju, T.: Electrochemical Cell Design and Development for Mediated Electrochemical Oxidation$\mathrm{Ce}(\mathrm{III}) / \mathrm{Ce}(\mathrm{IV})$ System. 114, pp. 55-65. Chemical Engineering Journal, (2005) 